\title{
JUURNAL.RU
}

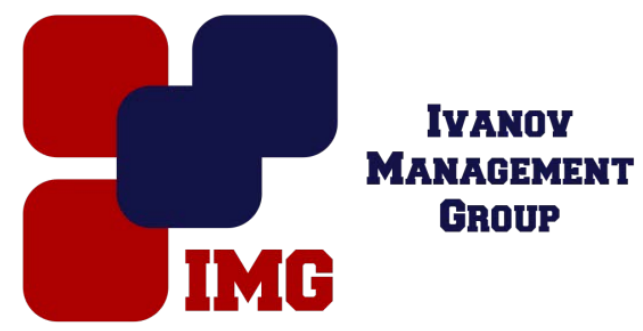

Галышев А.Б.

МАДИ

Москва, Россия

doi: 10.18411/lj-31-10-2016-3-02

idsp 000001:lj-31-10-2016-3-02

\section{Методы защиты велосипедистов от автотранспортных выбросов и автотранспортного шума}

Рост автомобильного парка в городах России приводит к росту числа дорожно-транспортных происшествий (ДТП), отчуждению территорий под автомобильные дороги и стоянки, загрязнению окружающей среды выбросами загрязняющих веществ (3В), повышению уровня транспортного шума, возрастанию заболеваемости населения и др. [1]. Альтернативой автомобилю могут служить такие экологически чистые виды транспорта, как велосипед. В настоящее время только жители Москвы имеют свыше 3 миллионов велосипедов, используемых, в основном, для рекреационных, спортивных, оздоровительных и туристических целей. Во многих городах появляются велосипедные дорожки, велопарковки и даже современная система велопроката [1]. Однако по мере роста числа велосипедистов, все более актуальной становится проблема улучшения условий их движения в рамках уличнодорожной сети (УДС). В частности проблема воздействия на них выбросов ЗВ автотранспортом и автотранспортного шума.

Защита велосипедистов от выбросов 3В.

Наиболее целесообразным решением для защиты велосипедистов от 3В,выбрасываемых автотранспортом, является полное разделение транспортных потоков (ТП). При этом для повышения эффективности данного метода расстояние между ними должно быть по возможности большим, а на разделительной полосе целесообразно размещать любые сооружения, 
препятствующие распространению загрязненного воздуха (Рис. 1), а еще лучше устроить полосу зеленых насаждений. При этом при посадке должно быть обеспечено плотное примыкание крон деревьев между собой, а пространство между ними заполнено кустарником. Породы деревьев и кустарников должны быстро расти и быть устойчивы к условиям воздушной среды в городах[2].

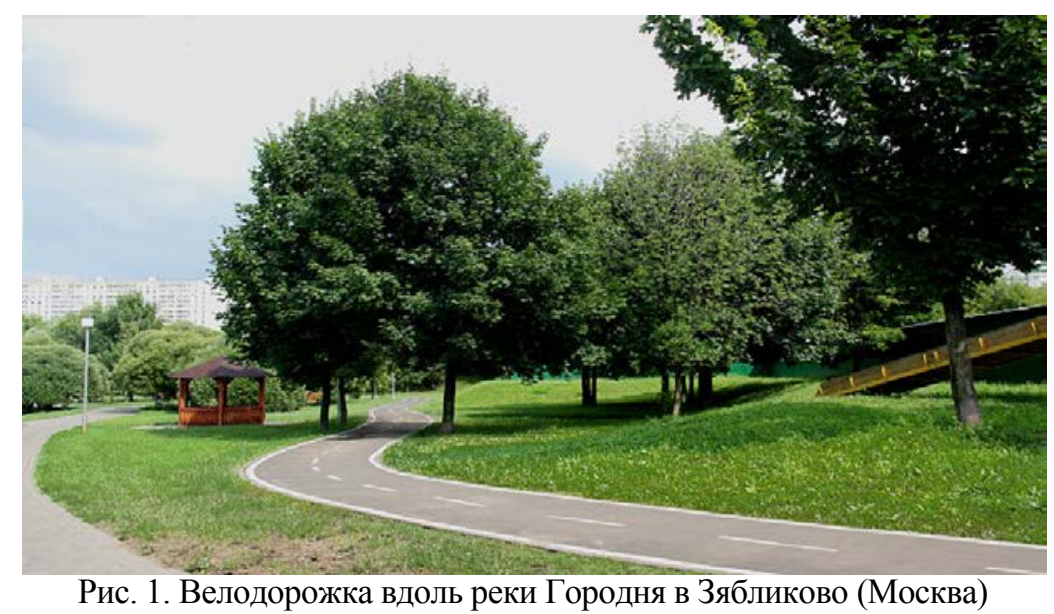

Однако планировка городской УДС не всегда позволяет разделить велосипедный и автомобильный ТП. В частности в исторических центрах крупных городов ширина улиц не всегда позволяет выделять отдельные велополосы. Поэтому велосипедистам, которым приходится перемещаться вдоль проезжей части, рекомендуется применять средства индивидуальной защиты (СИЗ) [3]. К ним относятся различные приспособления от простой марлевой повязки до специальной маски, снабженной сорбционным фильтром и действующей по принципу мини противогаза. Такие СИЗ позволяют более или менее эффективно защитить велосипедиста от выбросов ЗВ, но имеют ряд недостатков, прежде всего, ухудшают внешний вид велосипедиста и снижают комфортность поездки. Поэтому некоторые производители идут дальше и пытаются внедрить систему очистки воздуха непосредственно в конструкцию велосипеда. Интересным образцом является Air-PurifierBike, разработанный в Таиланде [4]. Он оснащен воздушным фильтром, собирающим частицы пыли и загрязнений, вырабатывающей кислород системой фотосинтеза (с водным резервуаром), электромотором и аккумулятором (Рис.2). Принцип его работы таков: во время езды воздух проходит сквозь фильтр, установленный на передней части велосипеда, где он очищается, а затем выдувается на велосипедиста. В полости рамы установлена система фотосинтеза. Во время 
простоя функции очистки воздуха продолжают работать за счет аккумулятора [4].Справедливости ради, стоит отметить, что пока неясны многие технические параметры функционирования таких велосипедов. В частности, еще не определено, каким именно образом они будут функционировать, при какой скорости движения будет происходить очистка воздуха и т.п. Но, безусловно, современное развитие технологий позволит решить имеющиеся проблемы. И кто знает, может уже в ближайшем будущем, такие велосипеды будут выпускаться массовым тиражом, что позволит еще эффективнее использовать этот экологически чистый вид транспорта.

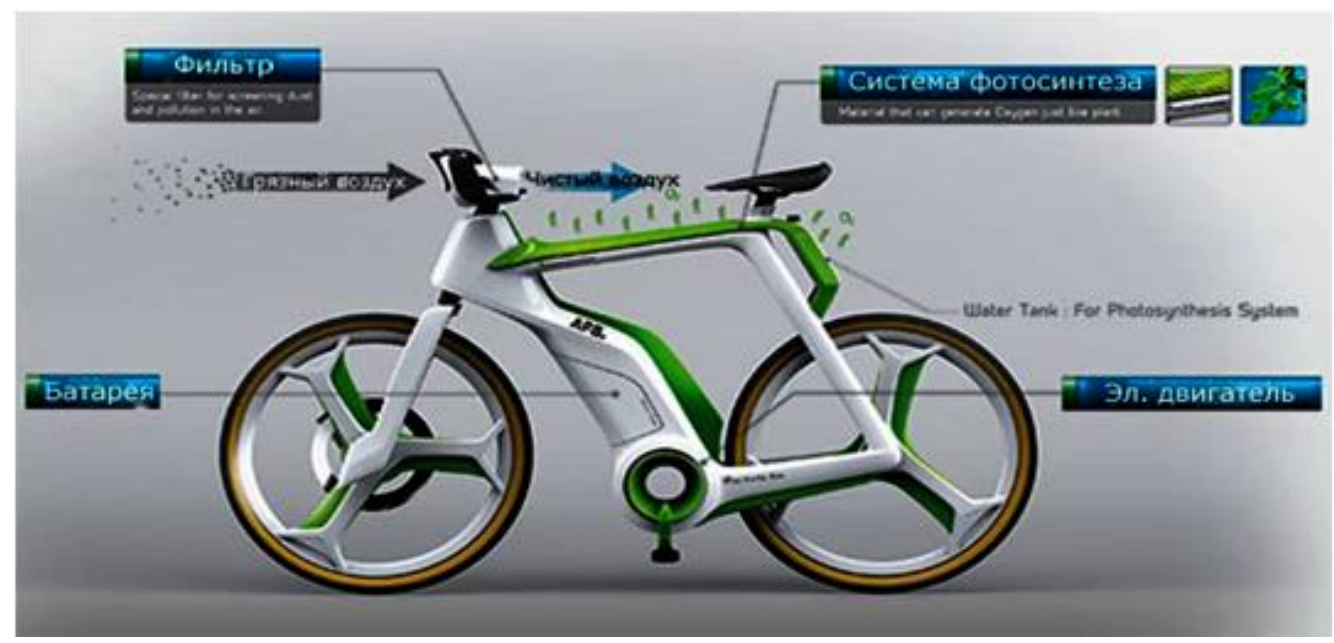

Рис. 2. ВелосипедAir-PurifierBike с системой очистки воздуха

Большое значение для обеспечения защиты велосипедистов и других участников дорожного движения от выбросов ЗВ является качество моторного топлива. С конца 80-х годов прошлого века по всему миру последовательно вводились экологические стандарты, регулирующие содержание основных ЗВ в выхлопных газах автомобиля. В России, например, с 1 января 2016 года на все ввозимые автомобили действует стандарт Евро-5. В то время как в Европе с 2015 года действует стандарт Евро-6, предъявляющий гораздо более жесткие требования к выбросам оксидов азота и углеводородов. Соответствие автомобиля данным экологическим классам может определяться не только по году выпуска, но также и по некоторым техническим особенностям, например пробег, наличие систем снижения вредных выбросов или переоборудование двигателя под стандарт Евро 5 или Евро-6. Строгое соблюдение требований экологических стандартов позволяет снизить выбросы ЗВ автопарком в несколько раз и поддерживать значения их концентраций в атмосфере на 
уровне, близком к допустимому. Уже у автомобиля, выполняющего нормы Евро-5, выхлоп в некоторых аспектах оказывается даже чище всасываемого воздуха. Таким образом, значительно снижается воздействие автотранспортных выбросов на велосипедистов, а возможности развития велотранспорта в городах, наоборот, значительно повышаются.

\section{Защита велосипедистов от транспортного шума.}

К основным СИЗ от автотранспортного шума относятся специальные шлемы, наушники, ушные вкладыши. Данные средства могут достаточно эффективно защитить движущегося по проезжей части велосипедиста от шумового воздействия (снижение уровня звукового давления не менее, чем на 10 дБА). Однако с другой стороны, их применение препятствует получению слуховой информации и может существенно увеличить риск попадания велосипедиста в ДТП. Поэтому лучше использовать методы коллективной защиты участников дорожного движения. Выделяют 3 мероприятия[5]:

1) Перепланировка типичной городской улицы с двухполосным движением в велопешеходную зону.

2) Ограничение скорости движения автотранспорта на городской улице до 30 км/ч $\quad$ с организацией совмещённого автомобильновелосипедного движения.

3) Устройство велосипедной дорожки вместо крайней правой полосы проезжей части на улицах с различным количеством полос проезжей части.

При этом первое мероприятие позволяет практически полностью исключить воздействие транспортного шума на велосипедистов, но, к сожалению, не может быть применено повсеместно. Применение второго мероприятия позволяет обеспечить лишь частичную защиту велосипедистов от автотранспортного шума: в среднем снижение скорости на 10 км/ч позволяет снизить уровень шума автотранспортного потока на 1,5 дБА[2]. Но в то же время возможности для его внедрения несравненно шире. Оно может эффективно работать как в центральной части крупных городов, так и в спальных районах. Резкое ограничение скорости движения при сохранении сравнительно высокой его интенсивности может привести к массовому переходу местного населения на использование велосипедного транспорта, что 
еще больше ускорит темпы его развития [5].Наконец третье мероприятие работает по тому же принципу, что и в случае с выбросами ЗВ.Величина снижения воздействия транспортного шума на велосипедистов тем больше, чем больше расстояние между проезжей частью и велодорожкой. При этом, если позволяет экологическая ситуация в городе, для зеленых насаждений лучше использовать хвойные породы (до 2 дБА к эффективности защиты).

Особняком среди транспортных сооружений для велодвижения стоит велополитен. Он представляет собой надземную систему специальных тоннелей для передвижения велосипедистов (Рис. 3). Достоинством данной системы является ее полная изолированность от прочих элементов УДС[1]. Поэтому перемещающийся в пределах велополитена велосипедист надежно защищен от воздействия выбросов ЗВ и автотранспортного шума даже в том случае, если тоннель располагается непосредственно над проезжей частью. А при наличии в тоннеле качественной системы вентиляции, там может быть обеспечена большая чистота воздуха, чем в рамках городской УДС. В этом случае любая поездка принимает черты рекреационной, что еще больше способствует укреплению здоровья велосипедистов.

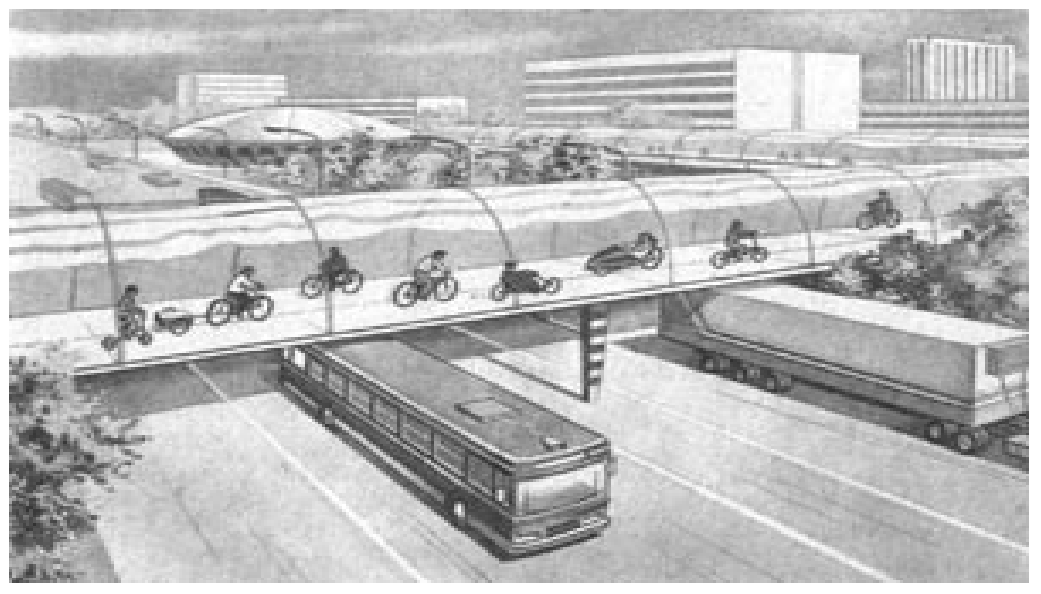

Рис. 3. Внешний вид велополитена.

\section{Вывод.}

Проведенные исследования доказывают, что хотя выбросы ЗВ автотранспортом и автотранспортный шум весьма негативно влияют на здоровье велосипедистов, на сегодняшний день существуют эффективные мероприятия для борьбы с их воздействием.А это значит, что современная экологическая ситуация в крупных городах России, хотя и не может считаться 
удовлетворительной, не является серьезной помехой для развития велосипедного движения

\section{Литература}

1. Трофименко Ю. В., Сова А. Н, Буренин В. В., Галышев А. Б. О необходимости развития велосипедного транспорта в крупных городах России // Автомобильный транспорт. - М., 2014. - №3. - С.70-74.

2. Шелмаков С. В. Расчетная оценка шума: методические указания к расчетным работам по курсу «Экология» / под ред. Н. П. Лапиной; МАДИ. - 1-е изд. - М.: МАДИ, 2009. - 34 с. - (МАДИ).

3. EleanorRoss. Anti-pollutioncyclingmaskstested[Электронный pecypc] // TheGuardian. - Текст.и граф. дан. - Wednesday 7 October 201511.08 BST. Систем.требования: AdobeReader. - URL: https://www.theguardian.com/environment/bike-blog/2015/oct/07/avoidingpollution-on-bike-we-test-cycling-anti-pollution-masks-respro-totobobobiologic(дата обращения: 07.10.2016).

4. AirPurifierBike - уникальный велосипед для очистки воздуха[Электронный ресурс] // Вело Среда. - Текст. и граф. дан. - 2014. - Систем.требования: AdobeReader. - URL: http://velosreda.ru/air-purifier-bike-unikalnyj-velosipeddlya-ochistki-vozdukha(дата обращения: 07.10.2016).

5. Галышев А. Б., Шелмаков С. В. Оценка потенциального акустического эффекта от внедрения мероприятий по развитию велосипедного движения в городах // Инновационное развитие современной науки: сборник статей Международной научно-практической конференции (30-31 мая 2014 г., г. Уфа). - Уфа, РИО МЦИИ «ОМЕГА САЙНС». - 2014. - С. 79-85. 